\title{
Comparison of HLA and Non-HLA Antibodies Regarding to Rejection Pattern of the Kidney Transplantation
}

\author{
Böbrek Transplantasyonunda Rejeksiyon Paternine Göre \\ HLA ve Non-HLA Antikorlarının Karşılaştırılması
}

Özgün Araştırma Research Article

Received/Geliş: 11.02 .2019 Accepted/Kabul: 03.06.2019 Published Online: 31.08 .2020

Tülay Kılıçaslan Ayna İmir Katip Çelebi Üniversitesi, Tip Fakültesi, Tibbi Biyoloji ve Genetik Anabilim Dalı, izmir - Türkiye

tulayayna@gmail.com ORCID: 0000-0001-8071-2814

M. Soyöz 0000-0001-5159-6463 B. Çerçi 0000-0002-7477-1073 A. Ö. Koçyiğit 0000-0002-0015-7070 i. Pirim 0000-0001-8485-3286 İmir Katip Çelebi Üniversitesi, Tıp Fakültesi, Tıbbi Biyoloji ve Genetik Anabilim Dalı, İmir, Türkiye

Cite as: Soyöz M, Killıçaslan Ayna T, Çerçi B, Özkızılcık Koçyigit A, Pirim I. Comparison of HLA and Non-HLA antibodies regarding rejection pattern of the kidney transplantation. Tepecik Eğit. ve Araşt. Hast. Dergisi. 2020;30(2):156-63.

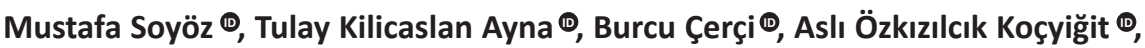 \\ Ibrahim Pirim $\odot$
}

\section{ABSTRACT}

Objective: Antibodies against HLA class I and II antigens are important in kidney transplantations because they cause rejections. Not only antibodies against HLA antigens but also those against non-HLA antigenic system play a role in antibody mediated rejections. In this study it was aimed to detect HLA-and non-HLA antibodies in individuals that experienced rejection attack.

Method: Thirteen patients, who clinically experienced rejection episodes according to the biochemical test results after transplantation, were tested by lymphocyte crossmatch (by using the lymphocytes of their living related donors) and non-HLA specific anti-endothelial crossmatch methods.

Results: Antibodies specific for Tie-2 receptor positive cells were not detected. The results of XM-ONE cross-match and flow crossmatch tests were found to be compatible with each other.

Conclusion: In conclusion, it was considered that immunosuppressive treatment protocols and surgical complications play important role in rejection attacks. Further studies can contributed to determination of graft survival.

Keywords: HLA antibodies, Non-HLA antibodies, organ transplantation, rejection, kidney transplantation

Öz

Amaç: HLA Sınıf I ve sınıf II antijenlerine karşı oluşmuş antikorlar böbrek nakillerinde rejeksiyon sebebi oldukları için önemlidirler. Sadece HLA antijenlerine karşı değil non-HLA antijenik sistemlere karşı üretilen antikorlar da antikor aracılı rejeksiyonda rol oynarlar. Bu çalışmada rejeksiyon atağı geçiren kişilerde HLA ve non-HLA antikorlarının belirlenmesi amaçlanmıştır.

Yöntem: Transplantasyondan sonra biyokimya test sonuçlarına göre rejeksiyon atağı geçiren 13 hasta lenfosit crossmatch (canlı-akraba donörlerinden alınan lenfositler kullanılmıştır) ve non-HLA spesifik anti-endoteliyal crossmatch yöntemleri ile test edildi.

Bulgular: Tie-2 reseptörüne spesifik belirlenmedi. XM-ONE crossmatch ve flow crossmatch test sonuçları birbirileri ile uyumlu bulundu.

Sonuç: Sonuç olarak rejeksiyon ataklarında immunsupresif tedavi protokolleri ve cerrahi komplikasyonlar önemli rol oynadığı düşünülmelidir. Gelecekteki çalışmalar greft yaşam ömrünün belirlenmesine katkı sağlayabilir.

Anahtar kelimeler: HLA antikorları, Non-HLA antikorları, organ nakli, rejeksiyon, böbrek nakli

\footnotetext{
(C) Telif hakkı T.C. Să̆lık Bakanlığı izmir Tepecik Eğit. ve Arast. Hastanesi. Logos Tıp Yayıncılık tarafindan yayınlanmaktadır. Bu dergide yayınlanan bütün makaleler Creative Commons Atf-GayriTicari 4.0 Uluslararası Lisansı ile lisanslanmıştr.

2. Copyright Association of Publication of the T.C. Ministry of Health Izmir Tepecik Education and Research Hospital. This journal published by Logos Medical Publishing.

Licenced by Creative Commons Attribution-NonCommercial 4.0 International (CC BY)
} 


\section{INTRODUCTION}

Kidney transplantation has an important impact on mortality, morbidity and quality of life compared with dialysis. In spite of the developments in transplantation \%10-30 of the dialysis patients awaiting renal transplantation have alloimmunity. Therefore the success of the transplantation is depend on preventing acute and chronic rejections due to alloimmunity ${ }^{(1)}$.

Both humoral and cellular components of the immune system are involved in the immune response against the allograft. In kidney transplantations the importance of antibodies that are produced against HLA class I and II antigens is an indisputable fact ${ }^{(2)}$. Conventional crossmatch tests (XM), in which lymphocytes of the donor were used, Flow Crossmatch (FCXM), complement-dependent crossmatch (CDCXM) and lymphocyte crossmatch (LXM) have been applied in routine tests ${ }^{(3,4)}$. Some solid phase techniques are specialized for detecting and identifying anti- HLA antibodies of patients on the transplant waiting list ${ }^{(5,6)}$. It is also known that even if LXM test results are negative, rejections may occur after transplantation ${ }^{(7-9)}$. Although XM test results are negative, $10-15 \%$ of kidney failures may be detected in the first year after transplantation ${ }^{(10)}$. Although these antibodies can be post-transplant anti-HLA antibodies, non-HLA antibodies can also play an important role.

Terasaki ${ }^{(11)}$ reported that $43 \%, 18 \%$, and $38 \%$ of the failed transplantations performed between full match siblings are caused by non-immunologic factors, HLA antigens, and non HLA antigens, respectively. In a case study Jackson et al. ${ }^{(12)}$ indicated that the patient who had not shown any signs of the antibody-related rejection, lost the transplant kidney.because of the presence of positive antiendothelial crossmatches.

In this study, investigation of the anti-HLA antibodies that play a role in post-transplantation rejection etiology was intended which revealed the association between non-HLA antibodies, rejection and graft survival. For this purpose, lymphocyte crossmatch methods and non-HLA specific anti-endothelial crossmatch tests were used and compared.

\section{MATERIALS and METHOD}

\section{Patients}

We evaluated the crossmatch tests among 13 patientdonor couples registered to Tepecik Training and Research Hospital Tissue Typing Laboratory in Izmir, Turkey. Demographic and alloimmunization information of the patients were shown in Table 1. Study population consisted of 3 female (23.1\%) and 10 male $(76.9 \%)$ patients. The mean age of the patients was $32.15 \pm 16$ years. The patients remained on dialysis for an average of 23.5 months before transplantation. The laboratory findings that are reflected in the patient's clinic are given in Table 1.

Table 1. Patient's and donor's characteristics.

\begin{tabular}{lc}
\hline Characteristics & $\mathbf{n}$ \\
\hline N of the patients & 13 \\
Mean age of the patients & $32.15 \pm 16$ \\
The mean duration of hemodialysis before tx (months) & 23.5 \\
Gender & \\
$\quad$ Female & 3 \\
$\quad$ Male & 10 \\
Cause of chronic renal failure & \\
Hypertension & 4 \\
Glomerular nephrite & 2 \\
FSGS Protein Leakage & 1 \\
FMF Amyloidosis & 1 \\
Vesicoureteral reflux & 1 \\
Nephropathic syndrome & 1 \\
NK & 3 \\
Blood transfusion(n of person) & 7 \\
Pregnancy (n of person) & 1 \\
Date of Rejection attack after tx (year) & \\
$<1$ & 7 \\
$>1$ & 6 \\
Donor & \\
Maternal & 5 \\
Paternal & 1 \\
Sibling & 3 \\
Grand parent & 3 \\
\end{tabular}

$N$, number; tx, transplantation; FSGS, Focal Segmental Glomerulosclerosis; FMF, Familial Mediterranean Fever; NK, not known 
Participants had negative lymphocyte crossmatch test results before transplantation and applied to our laboratory with clinically defined rejection episode according to the biochemical test results. Biopsy was applied to 3 patients during the follow-up. The study was explained to the patient-donor pairs (living related donors) and informed consent documents were signed by them. Antibody detection tests (CDCXM, Donor specific antibody (DSA), FCXM, panel reactive antibody test (PRA)) which have been performed routinely to the patients having rejection episodes were applied parallel with the tests of this project.

This study was approved by the ethics committee of Izmir Katip Celebi University (registration number: 21 , and dated 02.07. 2013) before initiation of the study. The patients were informed and signed the written informed consent.

\section{Immunosuppression protocols}

The immunosuppressive maintenance therapy consisted of tacrolimus, prednisolone and basiliximab.

\section{Human Leucocyte Antigen Typing}

HLA-A, B, and DRB1 loci of patients and potential donors were molecularly typed on genomic DNA using polymerase chain reaction-sequence specific oligonucleotides (SSO) (Lifecodes $^{\circledR}$, Immucor Transplant Diagnostics Inc, Stamford, CT, USA) as described by the manufacturers.

\section{Human leucocyte antigen antibody detection}

The levels of panel-reactive antibodies (PRA) in preand post-transplantation sera of the patients were determined using the Luminex-based method. (Luminex200). In the Luminex-based system an MFI value of $>1000$ above negative control was judged as positive. Antibody screening and identification were performed according to the instruction manual (Lifecodes ${ }^{\circledR}$ LifeScreen Deluxe, Lifecodes Class I ID, Lifecodes Class II ID, Immucor Transplant Diagnostics Inc, Stamford, CT, USA). On the other hand, besides LXM, donor specific antibodies (DSA) were determi- ned after transplantation by Luminex-based method (Lifecodes $^{\circledR}$ Donor Specific Antibody, Immucor Transplant Diagnostics Inc, Stamford, CT, USA).

\section{Complement-dependent cytotoxicity}

The standard CDC assay was performed as previously described (Terasaki, 1964). T and B lymphocytes were isolated from whole blood of donors by antiCD8 and CD19-conjugated magnetic beads (One Lambda $T$ and $B$ cell isolation reagent). Rabbit complement was used at optimal dilution for lysis of the cells.

\section{Flow cytometric lymphocyte crossmatch tests}

$T$ and $B$ cell flow crossmatch analyses were performed to the all of the patients. A $25 \mu$ l cell suspension separated by magnet and transferred to another tube, was distributed into 3 tubes for negative and positive controls, along with crossmatch. A $25 \mu \mathrm{l}$ control and patient sera were added and incubated for $30 \mathrm{~min}$ at room temperature. After incubation, $1 \mathrm{ml}$ isotonic solution was added and centrifuged at $1900 \mathrm{rpm}$. This step was repeated 3 times. Following this, $5 \mu \mathrm{l}$ CD3-PerCP and CD19-PE (BD, CA, ABD) monoclonal antibodies and $50 \mu \mathrm{l}$ anti-human IgGFITC (Dako, Glostup, Denmark) secondary antibody were added. After incubation at room temperature for $30 \mathrm{~min}$, the cells were washed twice. A $500 \mu \mathrm{l}$ isotonic solution was added to the tubes, and the samples were analyzed using FacsCalibur Flow Cytometry. The results were evaluated according to XM median/negative control median >1.46.

\section{Isolation of Endothelial progenitor cells}

Endothelial progenitor cells (Tie-2+ cells) were isolated from peripheral blood using a commercially available kit, as described by the manufacturer (AbSorber AB, Stockholm, Sweden). A $32 \mathrm{ml}$ blood sample was collected, and distributed into four Vacutainer CPT (BD, Franklin Lakes, NJ) tubes with heparin, and centrifuged for $15 \mathrm{~min}$ at $1650 \mathrm{~g}$. Peripheral mononuclear blood cells were collected from the bottom of the gel layer. The cells were incubated with paramagne- 
tic nanobeads that transported Tie-2- specific antibodies for $30 \mathrm{~min}$ on ice. After incubation, Tie-2+ cells were separated via magnet by incubating them for $20 \mathrm{~min}$ at room temperature. After incubation, the supernatant was transferred to another tube and used for lymphocyte crossmatch tests. Then $350 \mu \mathrm{l}$ isotonic solutions were added to the Tie- $2+$ cells.

\section{Endothelial cell crossmatch}

Endothelial cell crossmatch and $T$ and $B$ cell flow crossmatch were performed simultaneously. Fifty microliters of Tie-2+ cell suspension (1x106 cell in every fraction) were distributed into flow cytometry tubes $(12 \times 75 \mathrm{~mm})$. In total, 6 tubes were used for negative control, positive control, and crossmatch for both IgG and IgM. A $4 \mathrm{ml}$ isotonic solution was added and centrifuged for $5 \mathrm{~min}$ at $450 \mathrm{~g}$. Next, the washing step was twice repeated. After the last washing step, $50 \mu$ control and patient sera were added (sera of the patients were centrifuged at $4000 \mathrm{rpm}$ for $5 \mathrm{~min}$ before analysis). The tubes were incubated

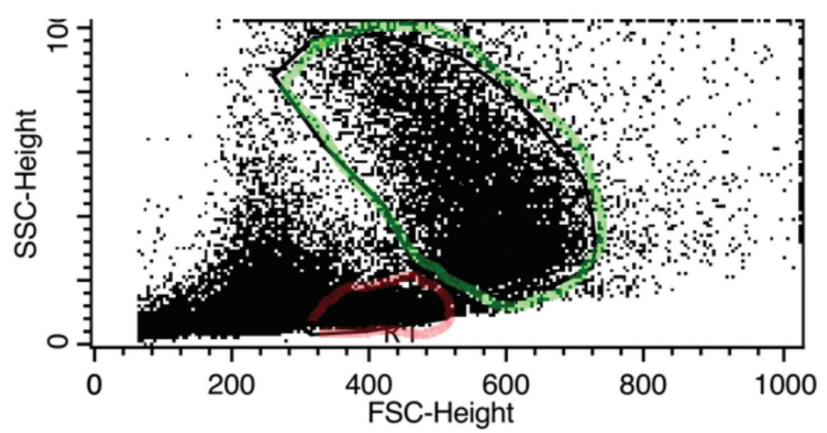

Figure 1. Lymphocyte and endothelial precursor cells cluster. The red area illustrates lymphocytes; green area shows endothelial precursor cells.

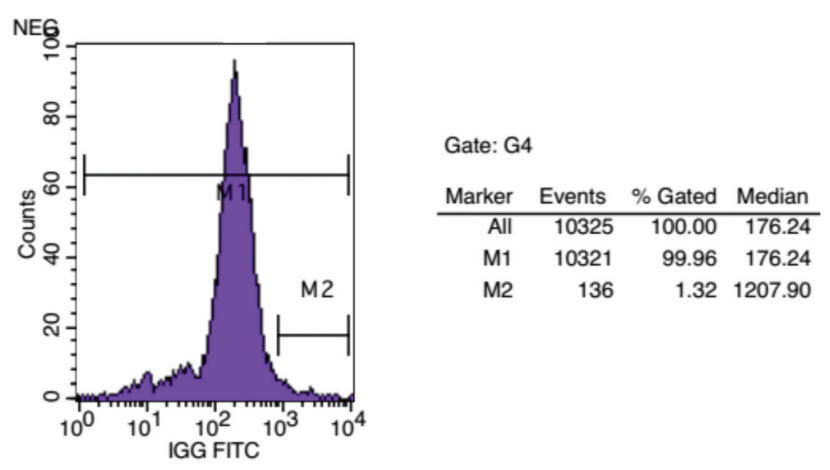

Figure 2a. Negative control IgG group endothelial cross match M1 value. for $30 \mathrm{~min}$ at room temperature. When the incubation period was over, a $4 \mathrm{ml}$ isotonic solution was added to each tube and centrifuged at $450 \mathrm{~g}$ for 5 min. This washing step was repeated for 3 times. Following this, $10 \mu \mathrm{l} \mathrm{CD3-PerCP}$ and CD19-PE monoclonal antibodies and $10 \mu \mathrm{l}$ anti-human IgG-FITC and anti-human IgM-FITC secondary antibodies were added. The tubes were incubated for $30 \mathrm{~min}$ at $+4^{\circ} \mathrm{C}$ in the dark. After incubation, cells were washed twice with a cold isotonic solution. A $300 \mu$ isotonic solution was added to the tubes and the results were analyzed using FacsCalibur Flow Cytometry.

\section{Assessment of the XM Results}

Endothelial crossmatch T (XM-ONE T LXM) and B (XM-ONE B LXM) results were analyzed simultaneously and compared with the results of the T FCXM and B FCXM that were performed for routine analysis. In order to determine the group of the cells, SSCFSC distribution graphics were used (Figure 1). Graphics of median values (M1) (Cell/IgG-FITC medi-

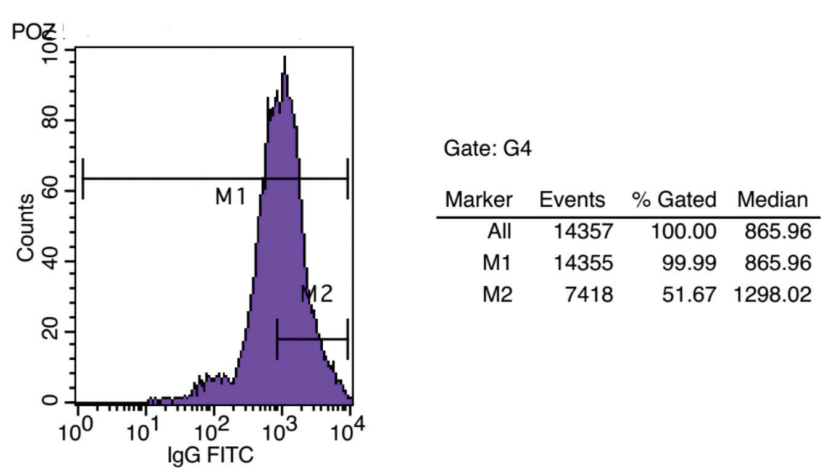

Figure 2b. Positive control IgG group endothelial cross match M1 value.

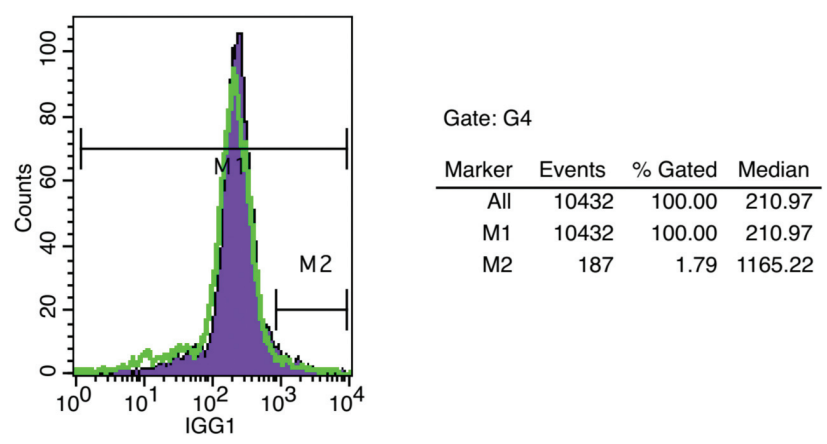

Figure 2c. Patient serum IgG group endothelial cross match M1 value. Green peak: Negative control peak 
an fluorescence intensity) evaluated for XM-ONE ECXM results were shown in Figure $2 \mathrm{a}, 2 \mathrm{~b}$, and $2 \mathrm{c}$. All of the patients' M1 value / M1 value of negative control (Figure 2a) was assessed by considering M1 value of positive control (Figure $2 b$ ). T and B LXM M1 values in ECXM tubes were also assessed and shown in Figure 2c. The results of the ECXM were compared with the results of the routine crossmatch methods.

\section{Statistical Analysis}

The Pearson chi square test was used for statistical analysis. A $p$ value of $<0.05$ was considered statistically significant. Statistical analysis were performed using SPSS Version 21.0.

\section{RESULTS}

Thirteen patients numbered from 1 to 13 who had experienced rejection episodes, and applied to the Ministry of Health Izmir Tepecik Training and Research Hospital Tissue Typing Laboratory were included in the study in order to investigate the presence of anti-endothelial cell antibodies.

Pre-transplant PRA and crossmatch (CDCXM, FCXM or DSA) results were negative for all patients in $54 \%$ and $46 \%$ of the patients who applied to our laboratory with a rejection episode according to the biochemical test results within the first year and the

Table 2. Post transplantation PRA results.

\begin{tabular}{|c|c|c|c|c|c|c|c|}
\hline Patient & Patient HLA & Donor HLA & $\mathrm{Mm}$ & $\mathrm{CI}$ & CII & $\mathrm{Cl}$ & C II \\
\hline 3 & $\begin{array}{l}A^{*} 03 A^{*} 24 \\
B^{*} 35 B^{*} 41 \\
\text { DRB1 } 104 \text { DRB1*11 }\end{array}$ & $\begin{array}{l}A^{*} 02 A^{*} 24 \\
B^{*} 35 B^{*} 35 \\
\text { DRB1*11 DRB1*11 }\end{array}$ & $\begin{array}{c}1 \mathrm{~A} \\
1 \mathrm{~B} \\
1 \mathrm{DR}\end{array}$ & Pos & Pos & $\begin{array}{l}\text { anti-A2+CREGs } \\
\text { anti-A33+CREGs }\end{array}$ & $\begin{array}{l}\text { anti-DR8 } \\
\text { anti-DR7 } \\
\text { anti-DR4 }\end{array}$ \\
\hline 7 & $\begin{array}{l}A^{*} 03 A^{*} 02 \\
B^{*} 49 B^{*} 18 \\
\text { DRB1*01 DRB1*11 }\end{array}$ & $\begin{array}{l}A^{*} 01 A^{*} 03 \\
B^{*} 18 B^{*} 37 \\
\text { DRB1*11 DRB1*16 }\end{array}$ & $\begin{array}{c}1 \mathrm{~A} \\
1 \mathrm{~B} \\
1 \mathrm{DR}\end{array}$ & Pos & Pos & anti-A1 & $\begin{array}{l}\text { anti-DR16 } \\
\text { anti-DR15 }\end{array}$ \\
\hline 9 & $\begin{array}{l}\text { A*33 A*32 } \\
\text { B*51 B*14 } \\
\text { DRB1*01 DRB1*11 }\end{array}$ & $\begin{array}{l}A^{*} 32 A^{*} 26 \\
B^{*} 51 B^{*} 38 \\
\text { DRB1*15 DRB1*11 }\end{array}$ & $\begin{array}{c}1 \mathrm{~A} \\
1 \mathrm{~B} \\
1 \mathrm{DR}\end{array}$ & $\mathrm{Neg}$ & Pos & - & anti-DR16 \\
\hline 12 & $\begin{array}{l}\text { A*11 A*32 } \\
\text { B*51 } \\
\text { DRB1*11 DRB1*15 }\end{array}$ & $\begin{array}{l}A^{*} 01 A^{*} 11 \\
B^{*} 08 B^{*} 35 \\
\text { DRB1*11 DRB1*03 }\end{array}$ & $\begin{array}{c}1 \mathrm{~A} \\
2 \mathrm{~B} \\
1 \mathrm{DR}\end{array}$ & Pos & Pos & anti-A1 & $\begin{array}{l}\text { anti-DR7 } \\
\text { anti-DQ2 }\end{array}$ \\
\hline 13 & $\begin{array}{l}A^{*} 02 A^{*} 02 \\
B^{*} 15 B^{*} 56 \\
\text { DRB1*04 DRB1*04 }\end{array}$ & $\begin{array}{l}A^{*} 01 A^{*} 02 \\
B^{*} 15 B^{*} 39 \\
\text { DRB1*04 DRB1*11 }\end{array}$ & $\begin{array}{c}1 \mathrm{~A} \\
1 \mathrm{~B} \\
1 \mathrm{DR}\end{array}$ & Neg & Pos & - & $\begin{array}{l}\text { anti-DQ99 } \\
\text { anti-DQ6 +CREGS }\end{array}$ \\
\hline
\end{tabular}

NA; Not applicable; Mm, mismatch; PRA sp, PRA specific; PRA, panel reactive antibody; CREG, cross reactive groups; Cl, Class I; ClI, Class II; NEG, negative; POS, positive

Table 2. Post transplantation XM results.

\begin{tabular}{|c|c|c|c|c|c|c|c|c|c|c|c|c|}
\hline \multirow[t]{2}{*}{ Patient } & $\begin{array}{c}\text { XM-ONE } \\
\text { IgG }\end{array}$ & $\begin{array}{c}\text { XM-ONE } \\
\text { IgG }\end{array}$ & $\begin{array}{c}\text { XM-ONE } \\
\text { IgG }\end{array}$ & $\begin{array}{c}\text { XM- ONE } \\
\text { IgM }\end{array}$ & $\begin{array}{c}\text { XM- ONE } \\
\text { IgM }\end{array}$ & $\begin{array}{c}\text { XM- ONE } \\
\text { IgM }\end{array}$ & FCXM & FCXM & CDCXM & CDCXM & $\begin{array}{l}\text { Luminex } \\
\text { DSA }\end{array}$ & $\begin{array}{c}\text { Luminex } \\
\text { DSA }\end{array}$ \\
\hline & B LXM & T LXM & ECXM & B LXM & T LXM & ECXM & B & $\mathbf{T}$ & PBL & B & $\mathrm{Cl}$ & ClI \\
\hline 3 & POS & POS & NEG & NEG & NEG & NEG & POS & POS & NA & NA & NA & NA \\
\hline 7 & POS & POS & NEG & NEG & NEG & NEG & POS & POS & NA & NA & POS & POS \\
\hline 9 & POS & NEG & NEG & NEG & NEG & NEG & POS & NEG & NA & NA & NA & NA \\
\hline 12 & POS & POS & NEG & NEG & NEG & NEG & POS & POS & NEG & NEG & POS & POS \\
\hline 13 & POS & NEG & NEG & NEG & NEG & NEG & NA & NA & NEG & POS & NEG & POS \\
\hline
\end{tabular}

IgG, Immunoglobulin G; IgM, Immunoglobulin M; ECXM, Endothelial Cross Match; T LXM, Lymphocyte Cross Match T Lymphocyte; B LXM, Lymphocyte Cross Match B Lymphocyte FCXM, Flow cytometric Cross Match; CDCXM, Complement Dependent Cytotoxic Cross Match; DSA, Donor Specific Antibody; Cl, Class I; CII, Class II; NA; Not applicable; Neg, negative; Pos, positive 
second year after transplantation, respectively where the results of 3 of them were biopsy-proven. Antibodies against both class I and class II HLA antigens were detected by PRA method in 3 patients after transplantation. Antibodies against only class II HLA antigens were identified in 2 patients (Table 2).

As a result of post-tx ECXM, positivities for $T$ and $B$ LXM tests were detected for 3 patients and only B LXM was positive for 2 patients (Table 3 ).

In the donor-specific antibody test applied to the patients, antibodies against class I and class II were detected in 3 patients and class II antibodies in 1 patient in accordance with FCXM T and $B$ results. The results of XM-ONE lymphocyte crossmatch and conventional FCXM methods were found to be compatible with each other.

\section{DISCUSSION}

T cell-mediated rejection has remained the most common reason of acute rejection. However, 20-30\% of the episodes of acute rejection are due to humoral rejection. Circulating anti-donor reactive antibodies (usually to donor HLA antigens) need to be detected to confirm the diagnosis ${ }^{(13)}$.

Thanks to improvements in immunosuppressive therapies and reduction in the incidence of acute and chronic rejection, scientists started to pay attention to non-HLA antibodies as triggers of acute and chronic rejection. Most of them trigger endothelial cells, so called anti-endothelial cell antibodies (AECAs) ${ }^{(14)}$. The incidence of AECA has been reported to be higher in renal recipients with failed transplants than in healthy grafts at 1 year post-transplantation. AECA is detected in HLA-sensitized renal transplant candidates more than non-sensitized candidates ${ }^{(15)}$.

The detection of AECA is laborious, time consuming and impractical for routine analysis ${ }^{(16,17)}$. Most studies have been used ELISA and western blotting to detect AECA. Flow cytometry can be more useful to detect antibodies targeting antigens expressed on the surface of the endothelial cells ${ }^{(17)}$.

Alheim et al. ${ }^{(18)}$ detected HLA class I, class II specific, and non-HLA antibodies using Tie-2+ endothelial precursor cells simultaneously with XM-ONE method. Xavier et al. ${ }^{(19)}$ also found that the AECA -positive results were significantly associated with irreversible, and progressive graft dysfunction in 20/31 cases with poor prognosis. Using XM-ONE they reported that patients without HLA sensitization and acute rejection could be identified by AECA tests. Zitzner et al. ${ }^{(20)}$ reported important findings about the nature of AECAs. Notably, the presence of AECA antibodies is not the same in different potential donors of the same patient. In another study, investigators mention that the polymorphic nature of non-HLA antibodies may lead to sensitization similar to HLA antibodies.

Breimer et al. ${ }^{(7)}$ indicated that XM-ONE detected an antibody population not HLA-specific that was not detected by lymphocyte crossmatch, but strongly associated with rejection episodes and decreased kidney function in 3rd and 6th months. In addition, $54 \%$ of ECXM-positive patients did not undergo rejection during follow-up. This situation can be explained by the fact that some antigens that are present on the endothelial cell precursors may not be expressed in the renal vascular endothelium, may not be relevant to transplant rejection, or may contribute to chronic rejection.

In our study, ECXM-negativity was found among patients. Three of these patients were $T$ and $B$ cell crossmatch-positive after transplantation by FCXM and for both the results were confirmed by XM-ONE IgG crossmatch and Luminex DSA. In one of these patients' CDCXM result was negative for class I and class II antibodies. An explanation for this inconsistency may be that the CDCXM test performed with these serum samples yielded false negative results. 
Otherwise only class II antibodies were detected in the other two patients using FCXM and DSA tests. Both of them were confirmed by XM-ONE IGG XM results.

Biopsy was applied to 3 patients and during followup, rejection was observed among these 3 patients (23.1\%) according to the biopsy results. FCXM and Luminex DSA of these patients were identified as positive and donor-specific antibodies were detected. A patient with class I and class II positivity and two patients with class II positivity did not show a reposition during follow-up.

In our study, XM-ONE method was used to detect anti-endothelial antibodies of 13 patients who underwent renal transplantation for the treatment of chronic renal failure. AECAs were not detected in the patients. In a previous multi-centered study, it was shown that there was a positive correlation between XM-ONE positivity and rejection ${ }^{(21)}$. On the other hand Alheim et al. ${ }^{(16)}$ reported lack of any difference in the frequency of rejections in pretransplant ECXM+ and ECXM-groups. This difference is thought to be due to the use of immunosuppressive treatment protocols or surgical complications.

In addition, our study group was made up of related donors and all donors, except one, were first degree relatives (mother, father, sister), and there were maximum 3 mismatches. Close relatives may also be important for AECA compliance, and ECXM supports the negative results. Evaluation of ECXM results in addition to routine lymphocyte crossmatch tests in cadaveric transplants would be more important for the graft survival. The further development of ECXM method may contribute to the graft survival. On the other hand, by using ECXM method, T and B LXM results can be assessed using the same blood sample. Therefore both anti-HLA and non-HLA antibodies can be investigated by eliminating the need for more time and labor.
Ethics Committee Approval: Approval was obtained from İzmir Katip Çelebi University Faculty of Medicine Non-Pharmaceutical Clinical Research Ethics Committee (2013/21).

Conflict of Interest: There is no conflict of interest between the authors.

Funding: This manuscript was supported by Izmir Katip Çelebi University Scientific Research Projects Coordination. Project Number: 2013-1-TCSP- 13.

Informed Consent: Informed consent form had been signed by all of the volunteer patients.

\section{REFERENCES}

1. Kaczmarczyk M, Kotfis K, Biernawska J, et al. Effect of recipient sensitization (peak panel reactive antibodies) on 15-year survival after kidney transplantation. Transplant Proc. 2014;46(8):2699-2702. [CrossRef]

2. Terasaki PI. Humoral theory of transplantation. Am J Transplant. 2003;3:665-73. [CrossRef]

3. Scornik JC. Detection of alloantibodies by flow cytometry: relevance to clinical transplantation. Cytometry. 1995;22:25963. [CrossRef]

4. Terasaki PI, McClelland JD. Microdroplet assay of human serum cytotoxins. Nature. 1964;204:998-1000. [CrossRef]

5. Pei R, Lee JH, Shih NJ, et al. Single human leukocyte antigen flow cytometry beads for accurate identification of human leukocyte antigen antibody specificities. Transplantation. 2003;75:43-9. [CrossRef]

6. Zachary AA, Delaney NL, Lucas DP, Leffell MS. Characterization of HLA class I specific antibodies by ELISA using solubilized antigen targets: I. Evaluation of the GTI QuikID assay and analysis of antibody patterns. Hum Immunol. 2001;62:22835. [CrossRef]

7. Breimer ME, Rydberg L, Jackson AM et al. Multicenter evaluation of a novel endothelial cell crossmatch test in kidney transplantation. Transplantation. 2009;87:549-56. [CrossRef]

8. Cerilli J, Bay W, Brasile L. The significance of the monocyte crossmatch in recipients of living-related HLA identical kidney grafts. Hum Immunol. 1983;7:45-50. [CrossRef]

9. Kalil J, Guilherme L, Neumann J et al. Humoral rejection in two HLA identical living related donor kidney transplants. Transplant Proc. 1989;21:711-3.

10. Sumitran-Holgersson S. Relevance of MICA and other nonHLA antibodies in clinical transplantation. Curr Opin Immunol. 2008;20(5):607-13. [CrossRef]

11. Terasaki PI. Deduction of the fraction of immunologic and nonimmunologic failure in cadaver donor transplants. Clinical Transplants. 2003;449-52.

12. Jackson AM, Kuperman MB, Montgomery RA. Multiple hyperacute rejections in the absence of detectable complement activation in a patient with endothelial cell reactive antibody. Am J Transplant. 2012;12(6):1643-9. [CrossRef]

13. Michaels PJ, Fishbein MC, Colvin RB. Humoral rejection of human organ transplants. Seminars in Immunopathol. 2003;25(2):119-40. [CrossRef]

14. Sigdel TK, Sarwal MM. Moving beyond HLA: a review of $n H L A$ 
antibodies in organ transplantation. Hum Immunol. 2013;74(11):1486-90. [CrossRef]

15. Zhang Q, Reed EF. The importance of non-HLA antibodies in transplantation. Nature Rev Nephrol. 2016;12(8):484-95. [CrossRef]

16. Alheim M, AlMahri A, Nilsson J, Tydén G, Holgersson J. The outcome of the endothelial precursor cell crossmatch test in lymphocyte crossmatch positive and negative patients evaluated for living donor kidney transplantation. Hum Immunol 2013;74(11):1437-44. [CrossRef]

17. Delville M, Charreau B, Rabant M, Legendre C, Anglicheau D. Pathogenesis of non-HLA antibodies in solid organ transplantation: where do we stand? Hum Immunol. 2016;77(11):105562. [CrossRef]

18. Alheim $M$, Johansson SM, Hauzenberger $D$, Grufman $P$, Holgersson J. A flow cytometric crossmatch test for simulta- neous detection of antibodies against donor lymphocytes and endothelial precursor cells. Tissue Antigens. 2010;75(3):269-77. [CrossRef]

19. Xavier $P$, Aires $P$, Sampaio $S$ et al. XM-ONE detection of endothelium cell antibodies identifies a subgroup of HLAantibody negative patients undergoing acute rejection. Transplant Proc. 2011;43(1):91-4. [CrossRef]

20. Zitzner JR, Shah S, Jie C, Wegner W, Tambur AR, Friedewald JJ. A prospective study evaluating the role of donor-specific anti-endothelial crossmatch (XM-ONE assay) in predicting living donor kidney transplant outcome. Hum Immunol. 2013;74(11):1431-6. [CrossRef]

21. Sumitran-Holgersson S, Ge X, Karrar A, et al. A novel mechanism of liver allograft rejection facilitated by antibodies to liver sinusoidal endothelial cells. Hepatology. 2004;40:1211. [CrossRef] 